\title{
Pengaruh Pemberdayaan Keluarga terhadap Pengendalian Obesitas
}

\section{Family Empowerment Effect on Obesity Control}

\author{
Bertalina $^{1}$, Roza Mulyani ${ }^{2}$ \\ Jurusan Gizi, Politeknik Kesehatan Tanjung Karang, Indonesia
}

\section{ARTICLE INFO}

\section{Article history:}

Received date

19 Dec 2019

Revised date

24 Mar 2020

Accepted date

24 Apr 2020

\section{Keywords:}

Nutrient intake;

Obesity;

Physical activity;

Role models.

\section{Kata kunci:}

Asupan zat gizi;

Obesitas;

Aktifitas fisik;

Role model.

\author{
ABSTRACT/ ABSTRAK
}

\begin{abstract}
World's population 2,2 billion obesity. Besides, overweight and obesity have a risk of developing diabetes $(44 \%)$, ischemic heart disease $(23 \%)$, and cancer $(7-41 \%)$. The main risk factors that cause obesity are behavioral factors, which are unhealthy eating patterns, plus insufficient consumption of fiber (fruit and vegetables), lack of physical activity, and smoking. The study aimed to determine the effect of family empowerment on obesity control in Hajimena Public Health Center, South Lampung. The research variable was family empowerment with a balanced nutrition diet, routine physical activity measured before, and after being educated. The study was conducted in July-November 2018. The type of research was a Quasi experiment, the results of sample calculations obtained a sample of 66 people. The results showed there were differences in fat, vegetable, sugar, salt and sweet foods intake before and after intervention with a value of $\mathrm{p} 0,048,0,022,0,001,0,008$ and 0,025 . There was no difference in intake, energy, protein, carbohydrate, fruit, before and after the intervention with p-values of $0,576,0,229,0,583$, and 0,930 . There are differences in physical activity before and after the intervention with a p-value of 0,001 . The Health Center can collaborate with the school in overcoming obesity programs by conducting counseling in schools and evaluating nutritional status.
\end{abstract}

\begin{abstract}
Sebesar 2,2 miliar penduduk dunia mengalami kelebihan berat badan. Selain itu overweight dan obesitas memiliki risiko mengalami diabetes (44\%), penyakit jantung iskemik (23\%) dan kanker (7-41\%).Faktor resiko utama yang menyebabkan obesitas adalah factor perilaku yaitu pola makan yang tidak sehat ditambah konsumsi serat (buah dan sayur) tidak mencukupi, aktifitas fisik yang kurang dan merokok. Tujuan Penelitian adalah untuk mengetahui pengaruh pemberdayaan keluarga terhadap pengendalian obesitas Puskesmas Hajimena Lampung Selatan, Variabel penelitian adalah pemberdayaan keluarga dengan pola makan gizi seimbang, rutin melakukan aktifitas fisik yang diukur sebelum dan sesudah diberi edukasi. Penelitian dilakukan pada bulan Juli-November 2018. Jenis penelitian Quasi experiment, hasil perhitungan sampel diperoleh jumlah sampel 66 orang. Ada perbedaan asupan lemak, sayur, gula, garam dan makanan manis sebelum dan sesudah intervensi dengan nila $p$-value $(0,048,0,022,0,001,0,008$ dan 0,025). Tidak ada perbedaan asupan energi, protein dan karbohidrat, buah sebelum dan sesudah intervensi dengan nilai p-value 0,576 , 0,229 dan 0,583 dan 0,093 . Ada perbedaan aktivitas fisik sebelum dan sesudah intervensi dengan nilai $p$-value 0,001 . Puskesmas dapat bekerja sama dengan pihak sekolah dalam penanggulangan program obesitas dengan melakukan penyuluhan di sekolah dan mayarakat serta melakukan penilaian status gizi.
\end{abstract}

Corresponding Author:

\section{Bertalina}

Jurusan Gizi, Politeknik Kesehatan Tanjung Karang, Indonesia

Email:bertalina@poltekkes-tjk.ac.id

\section{PENDAHULUAN}

Penduduk dunia sejumlah 2,2 miliar mengalami kelebihan berat badan. Selain itu overweight dan obesitas memiliki risiko mengalami diabetes (44\%), penyakit jantung iskemik (23\%) dan kanker (7-41\%) (GBD 2015 Obesity Collaborators, 2017).

Di Indonesia, berdasarkan data Riset Kesehatan Dasar (Riskesdas), menunjukkan peningkatan prevalensi obesitas pada penduduk berusia $\geq 15$ tahun, dari $18,8 \%$ (2007), $26,6 \%$ 
(2013) dan 31\% (2018), begitu juga prevalensi obesitas pada usia $>18$ tahun dari 10,5\% (2010) menjadi 14,8\% (2013) dan meningkat menjadi 21,8\% tahun 2018 (Kemenkes RI, 2018).

Sebagian besar PTM terkait-gizi berasosiasi dengan kelebihan berat badan dan kegemukan yang disebabkan oleh kelebihan gizi. Data Riskesdas 2007, 2010, 2013 memperlihatkan kecenderungan prevalensi obes (IMT > 25) semua kelompok umur. Anak balita $12,2 \%, 14 \%$ dan 11,9\%; usia 6-19 tahun (Riskesdas 2007, 2010) naik dari 5,2\% menjadi $5,9 \%$; orang dewasa dan usia lanjut (Riskesdas 2007, 2010) naik dari 21,3\% menjadi 22,8\%. Pada Riskesdas 2013 laki-laki obes 19,7\% dan perempuan 32,9\% (Depkes RI, 2008; Depkes RI, 2010, Kemenkes RI, 2013). Kelebihan gizi ini timbul akibat kelebihan asupan makanan dan minuman kaya energi, kaya lemak jenuh, gula dan garam tambahan, namun kekurangan asupan pangan bergizi seperti sayuran, buah buahan dan serealia utuh, serta kurang melakukan aktivitas fisik (Kemenkes RI, 2014)

Obesitas disebabkan oleh beberapa faktor yaitu genetic, lingkungan, obat-obatan dan hormonal.Obesitas merupakan factor risiko penyakit degeneratif di Negara berkembang. Hal ini terjadi akibat perubahan gaya hidup masyarakat antara lain aktifitas fisik dan pola makan akibat perkembangan status sosial ekonomi masyarakat perkotaan dan pedesaan. Berdasarkan data Riskesdas tentang analisis Survei Konsumsi Makanan Individu (Atmarita, dkk., 2017), sebesar 40,7\% masyarakat Indonesia mengkonsumsi lemak, 53,1 mengkonsumsi makanan manis, 93,5\% kurang konsumsi sayur dan buah dan 26,1\% aktifitas fusik kurang. Konsumsi sayur dan olahannya hanya sebesar 57,1gr/orang/hari dari anjuran 200300gr/orang/hari dan konsumsi buah dan olahannya sebesar 33,5gr/orang/hari dari anjuran 3-5 penukar. Angka ini masih rendah sehingga belum mencukupi kebutuhan tubuh akan vitamin, mineral dan serat.

Penelitian Stettler, et al dalam Sartika (2011), menyatakan bahwa beberapa faktor penyebab obesitas pada anak antara lain asupan makanan berlebih, yang berasal dari jenis makanan olahan serba instan, minuman soft drink, makanan jajanan seperti makanan cepat saji (burger, pizza, hot dog) dan makanan siap saji lainya yang tersedia digerai makanan. Faktor penyebab lainnya adalah kurangnya aktivitas fisik. Faktor resiko utama yang menyebabkan obesitas adalah faktor perilaku yairu pola makan yang tidak sehat ditambah konsumsi serat (buah dan sayur) tidak mencukupi, aktifitas fisik yang kurang dan merokok.

Hasil pemantauan status gizi (2017), di kabupaten Lampung Selatan diketahui balita gemuk sebesar 5,3\% , angka ini lebih tinggi dari angka Provinsi Lampung (4,2\%) (Kemenkes RI, 2018). Untuk usia di atas 15 tahun (Depkes RI, 2008) diketahui angka obesitas $31,2 \%$ sementara angka provinsi sebesar 30,4. Berkaitan dengan itu, peneliti ingin mengetahui pengaruh pemberdayaan keluarga terhadap pengendalian obesitas di Puskesmas Hajimena kabupaten Lampung Selatan. Variabel penelitian adalah pemberdayaan keluarga dengan pola makan gizi seimbang, rutin melakukan aktifitas fisik dan memberi dukungan psikologis saling menyemangati untuk hidup sehat yang diukur sebelum dan sesudah diberi edukasi dengan memberikan booklet .

\section{METODE}

Rancangan penelitian yang digunakan dalam penelitian ini adalah quasi experiment tanpa control group. Dimana pengukuran dan pengumpulan data dilakukan sebelum dan sesudah dilakukan intervensi pada keluarga yang memiliki anak obesitas. Variabel penelitian adalah pemberdayaan keluarga dengan pola makan gizi seimbang, rutin melakukan aktifitas fisik dan memberi dukungan psikologis saling menyemangati untuk hidup sehat yang diukur sebelum dan sesudah dengan menggunakan kuesioner dan pemberdayaan dengan memberikan edukasi dengan menggunakan booklet. Jumlah sampel yang dibutuhkan dalam penelitian ini sejumlah 66 orang. Teknik pengambilan sampel adalah simple random sampling, dengan kriteria inklusi:

1) Keluarga yang mempunyai anggota keluarga usia >5-18 tahun menderita over weight dan obesitas.

2) Bersedia menjadi responden dalam penelitian ini.

3) Anggota keluarga dalam kondisi sehat

Penelitian ini telah melewati kaji etik dan mendapatkan Keterangan Kelaikan Etik (Ethical Clearance) dengan Nomor 160/EC/KEPTJK/VI/2018 oleh Komisi Etik Penelitian Kesehatan Kementerian Kesehatan Tanjung Karang. 
HASIL

Tabel 1. Distribusi Responden Berdasarkan Jenis Kelamin

\begin{tabular}{lrr}
\hline \multicolumn{1}{c}{ Jenis Kelamin } & n & \multicolumn{1}{c}{$\%$} \\
\hline Laki-laki & 30 & 45,5 \\
Perempuan & 36 & 54,6 \\
Jumlah & 66 & 100,0 \\
\hline
\end{tabular}

Hasil penelitian menunjukkan bahwa sebagian besar responden obesitas berjenis kelamin perempuan $54,6 \%$ dan yang berjenis kelamin laki-laki 45,5\%.

\section{Konsumsi Zat Gizi}

Tabel 2. Perbedaan Asupan Zat Gizi Menurut Pengukuran I dan II

\begin{tabular}{|c|c|c|c|c|}
\hline Variabel & $\mathbf{n}$ & $\begin{array}{c}\text { Mean } \\
(\text { Min-Max) }\end{array}$ & Rerata \pm s.b & p-value \\
\hline \multicolumn{5}{|l|}{ Konsumsi Energi } \\
\hline Sebelum intervensi & 66 & $1956,4(2342,1-2512,2)$ & $1956,4 \pm 231,5$ & \multirow{2}{*}{0,576} \\
\hline Sesudah Intervensi & 66 & $1942,9(1230,4-2489,6)$ & $1942,9 \pm 237,5$ & \\
\hline \multicolumn{5}{|l|}{ Konsumsi Protein } \\
\hline Sebelum intervensi & 66 & $45,7(31,5-67,9)$ & $45,7 \pm 7,9$ & \multirow{2}{*}{0,229} \\
\hline Sesudah Intervensi & 66 & $47,1(32,4-67,5)$ & $47,1 \pm 7,1$ & \\
\hline \multicolumn{5}{|l|}{ Konsumsi Lemak } \\
\hline Sebelum intervensi & 66 & $77,0(43-117,8)$ & $77,01 \pm 19,2$ & \multirow{2}{*}{0,048} \\
\hline Sesudah Intervensi & 66 & $73,7(35,7-110,9)$ & $73,68 \pm 18,8$ & \\
\hline \multicolumn{5}{|l|}{ Konsumsi KH } \\
\hline Sebelum intervensi & 66 & $271,6(271-459,1)$ & $271,6 \pm 59,8$ & \multirow{2}{*}{0,583} \\
\hline Sesudah Intervensi & 66 & $269,7(196,8-398,0)$ & $269,7 \pm 39,9$ & \\
\hline
\end{tabular}

Pada tabel 2 terlihat bahwa rata-rata konsumsi energi responden lebih dari kebutuhan yaitu $120,4 \%$ pada pengukuran pertama dan pada pengukuran kedua menjadi 119,8. Sedangkan untuk konsumsi protein rata-rata responden masih dibawah kebutuhan yaitu sebesar 75,4\% pada pengukuran pertama dan menjadi $77,6 \%$ pada pengukuran kedua. Untuk konsumsi lemak rata-rata responden sudah sangat melebihi kebutuahan yaitu $171,4 \%$ pada pengukuran pertama dan $163,7 \%$ pada pengukuran kedua. Begitu juga dengan rata-rata konsumsi $\mathrm{KH}$ juga telah melebihi kebutuhan yaitu $110,3 \%$ pada pengukuran pertama dan $109,5 \%$ pada pengukuran kedua.

Konsumsi energi sebelum intervensi dengan rata-rata $1956,4 \pm 231,5$. Konsumsi energi sesudah intervensi diperoleh rata-rata $1942,9 \pm 237,5$. Hasil analisis diperoleh nilai $p$ value 0,574. Konsumsi protein responden sebelum intervensi $45,7 \pm 7,9$ dan sesudah intervensi 47,1 7,1 dengan nilai $p$-value 0,229. Hasil tersebut menunjukkan ada perbedaan konsumsi protein responden sebelum dan sesudah intervensi.

Konsumsi lemak responden sebelum intervensi $77,0 \pm 19,2$ dan sesudah intervensi $73,7 \pm 18,8$ serta hasil analisis diperoleh nilai $p$ - value 0,048. Hasil tersebut menunjukan bahwa ada perbedaan asupan konsumsi lemak sebelum dan sesudah intervensi.

Konsumsi karbohidrat sebelum intervensi $271,6 \pm 66,9$ dan $269,7 \pm 49,9$ sesudah intervensi, hasil uji statistik diperoleh nilai $p$-value 0,779 , yang artinya ada perbedaan konsumsi karbohidrat sebelum dan sesudah intervensi.

\section{Peran Orang Tua sebagai Role Model}

Orang tua sangat berperan terhadap konsumsi makanan anak, pada tabel di bawah terlihat $100 \%$ ibu menyediakan sayur dalam makanan sehari-hari, sementara hanya 19,7\% orang tua menyiapkan buah-buahan dalam makanan sehari-hari. Sedangkan ibu yang melakukan aktifitas fisik hanya 10,6\%.

Tabel 3. Peran Orang Tua Sebagai Role Model

\begin{tabular}{lrrr}
\hline Orang Tua & \multicolumn{1}{c}{ Ya } & \multicolumn{1}{c}{ Tidak } & Jumlah \\
\hline Menyiapkan & 66 & 0 & 66 \\
$\begin{array}{l}\text { Sayur } \\
\text { Menyiapkan }\end{array}$ & $100 \%)$ & 53 & \\
$\begin{array}{l}\text { buah } \\
\text { Melakukan }\end{array}$ & $(19,7 \%)$ & $(80,3 \%)$ & 66 \\
aktifitas & 7 & 59 & \\
Fisik & $(10,6 \%)$ & $(80,4 \%)$ & 66 \\
\hline
\end{tabular}




\section{Perbedaan Konsumsi Buah dan Sayur}

Tabel 4. Perbedaan Konsumsi Buah dan Sayur Menurut Pengukuran I dan II

\begin{tabular}{ccccc}
\hline Variabel & $\begin{array}{c}\text { Mean }(\text { Min- } \\
\text { Max })\end{array}$ & n & Rerata \pm sd & p-value \\
\hline Konsumsi Buah & & & & \\
\hline Pengukuran I & $50,4(0,0-200)$ & 66 & $50,4 \pm 7,6$ & 0,930 \\
Pengukuran II & $51,3(0,0-230)$ & 66 & $51,3 \pm 67,1$ & \\
\hline Konsumsi Sayur & & & & 0,022 \\
\hline Pengukuran I & $18,3(0,0-10,5)$ & 66 & $18,3 \pm 25,2$ & \\
Pengukuran II & $29,5(0,0-100)$ & 66 & $29,5 \pm 31,4$ & \\
\hline
\end{tabular}

Hasil recall 24 jam pada responden di dapat konsumsi buah terlihat ada perbedaan sebelum 50,4 $\pm 7,6$ dan sesudah $51,29 \pm 67,1$ intervensi, namun hasil statistik menunjukkan tidak ada perbedaan yang bermakna dengan $p$ value 0,93 .

\section{Perbedaan Konsumsi Gula, Garam dan Minyak.}

Tabel 5. Perbedaan Konsumsi Gula, Garam dan Minyak Menurut Pengukuran I dan II

\begin{tabular}{cccrc}
\hline Variabel & Mean $($ Min-Max) & n & Rerata \pm SD & p-value \\
\hline Perilaku Konsumsi Gula & & & & \\
\hline Pengukuran I & $50,4(23,7-79,0)$ & 66 & $50,4 \pm 10,3$ & \multirow{2}{*}{0,001} \\
Pengukuran II & $55,1(32,7-70,6)$ & 66 & $55,1 \pm 10,7$ & \\
\hline Perilaku Konsumsi Garam & & & & \\
\hline Pengukuran I & $3,1(\mathrm{I}, 5-4,9)$ & 66 & $3,1 \pm 0,7$ & \multirow{2}{*}{0,008} \\
Pengukuran II & $3,3(2,1-4,9)$ & 66 & $3,3 \pm 0,7$ & \\
\hline Perilaku Konsumsi Lemak & & & & \\
\hline Pengukuran I & $77,0(171,4)$ & 66 & $77,0 \pm 19,2$ & \multirow{2}{*}{0,048} \\
Pengukuran II & $73,7(163,7)$ & 66 & $73,7 \pm 18,8$ & \\
\hline
\end{tabular}

Pada tabel 5 terlihat bahwa ada perbedaan antara konsumsi gula sebelum 50,4 $\pm 10,3$ dan sesudah 55,1 $\pm 10,7$ intervensi, dengan hasil uji statistik diperoleh nilai p-value 0,001. Begitu juga dengan konsumsi garam dimana hasil menunjukkan ada perbedaan antara konsumsi garam dengan sebelum $3,1 \pm 0,7$ dan sesudah $3,3 \pm 0$, intervensi, hasil uji statistik di dapat nilai p-value 0,008. Sedangkan konsumsi lemak menunjukkan ada perbedaan sebelum dan sesudah intervensi dengan nilai $p$-value 0,048 .
Begitu juga dengan konsumsi sayur terlihat ada perbedaan yang sebelum $18,3 \pm 25,2$ dan sesudah 29,5 $\pm 31,4$ intervensi. Hasil uji statistik menunjukkan ada perbedaan dengan $p$ value 0,022 .

\section{Perbedaan Konsumsi Minuman dan Makanan Manis}

Tabel 6. Perbedaan Frekuensi Minuman dan Makanan Manis Menurut Pengukuran I dan II

\begin{tabular}{ccccc}
\hline Konsumsi & $\begin{array}{c}\text { Frek } \\
\text { rata- } \\
\text { rata }\end{array}$ & $\begin{array}{l}\text { Min } \\
\text { Max }\end{array}$ & n & $\begin{array}{c}\boldsymbol{p} \text { - } \\
\text { value }\end{array}$ \\
\hline Minuman Manis & & & & \\
\hline Pengukuran I & $3,8 \pm 0,8$ & $2-5$ & 66 & 0,363 \\
Pengukuran II & $3,7 \pm 0,8$ & $2-5$ & 66 & \\
\hline Makanan Manis & & & & \\
\hline Pengukuran I & $3,1 \pm 0,8$ & $2-5$ & 66 & 0,025 \\
Pengukuran II & $3,4 \pm 0,7$ & $2-6$ & 66 & \\
\hline
\end{tabular}

Hasil penelitian menunjukkan tidak ada perbedaan konsumsi minuman manis sebelum $3,8 \pm 0,8$ dan sesudah $3,1 \pm 0,8$ intervensi dengan nilai $\mathrm{p} 0,363$. Sedangkan untuk makanan manis menunjukkan ada perbedaan sebelum dan sesudah intervensi dengan nilai $p$-value 0,025 . 


\begin{tabular}{|c|c|c|c|}
\hline \multicolumn{4}{|c|}{ Perbedaan Aktivitas Fisik } \\
\hline \multicolumn{4}{|c|}{$\begin{array}{l}\text { Tabel 7. Perbedaan Rata-Rata Aktifitas Fisik } \\
\text { Sebelun dan Sesudah Intervensi }\end{array}$} \\
\hline Variabel & Mean & Rerata $\pm s$ & $p-$ \\
\hline \multicolumn{4}{|l|}{$\begin{array}{l}\text { Aktivitas Fisik } \\
\end{array}$} \\
\hline $\begin{array}{ll}\text { Sebelum } & 66 \\
\text { intervensi }\end{array}$ & $\begin{array}{r}1,97 \\
(1,3-2,9)\end{array}$ & $1,97 \pm 0,5$ & 0,001 \\
\hline $\begin{array}{l}\text { Sesudah } \\
\text { intervensi }\end{array}$ & $\begin{array}{r}2,19 \\
(1,3-3,2) \\
\end{array}$ & $2,19 \pm 0,4$ & \\
\hline
\end{tabular}

Tabel 7 menunjukkan bahwa aktifitas fisik siswa sebelum intervensi dengan nilai mean (min-max) sebesar 2,2 (1-3,8) dan rata-rata $2,2 \pm 0,51$. Aktifitas fisik sesudah intervensi diperoleh nilai median 2,3 (1,3-4,5) dan rata-rata $2,4 \pm 0,5$. Hasil analisis diperoleh nilai $p$-value 0,001 .

\section{PEMBAHASAN}

\section{Konsumsi Zat Gizi}

Konsumsi energi rata-rata responden lebih tinggi dari kebutuhan yaitu rata-rata 120,44\% pada pengukuran pertama. Konsumsi energi setelah intervensi terlihat ada penurunan asupan energi walaupun penurunanya sangat kecil yaitu menjadi $119,8 \%$ pada pengukuran kedua. Keadaan obesitas terjadi jika makanan sehariharinya mengandung energi yang melebihi kebutuhan, terutama zat gizi makro yang menyebabkan kegemukan bila dimakan secara berlebihan. Zat gizi ini akan disimpan dalam bentuk lemak tubuh dan akan meningkatkan badan secara keseluruhan (Wulandari, 2017).

Sedangkan untuk konsumsi protein ratarata asupan responden masih di bawah kebutuhan yaitu sebesar $75,4 \%$ pada pengukuran pertama dan menjadi $77,5 \%$ pada pengukuran kedua terlihat ada peningkatan sedikit. Masa anak dan remaja merupakan masa pertumbuhan, sangat disayangkan jika konsumsi protein rendah karena akan mempengaruhi pertumbuhan anak.

Untuk konsumsi lemak rata-rata responden sudah sangat melebihi kebutuhan yaitu $171,4 \%$ pada pengukuran pertama dan $163,6 \%$ pada pengukuran kedua. Konsumsi lemak sangat lebih tinngi dari kebutuhan responden, mungkin inilah yang menjadi salah satu penyebab anak menjadi obesitas dimana konsumsi yang berlebih akan disimpan sebagai lemak didalam tubuh.

Begitu juga dengan rata-rata konsumsi $\mathrm{KH}$ juga telah melebihi kebutuhan yaitu $110,3 \%$ pada pengukuran pertama dan $109,5 \%$ pada pengukuran kedua, kelebihan karbohidrat juga akan disimpan dalam tubuh sebagai lemak.

Hasil penelitian menunjukkan bahwa konsumsi energi sebelum intervensi dengan ratarata 1956,4 $\pm 231,5$. Konsumsi anergi sesudah intervensi diperoleh rata-rata 1942,9 $\pm 237,5$. Hasil analisis diperoleh nilai p-value 0,574.

Konsumsi protein responden sebelum intervensi 45,7 77,9 dan p-value 0,229. Hasil tersebut menunjukkan ada perbedaan konsumsi protein responden sebelum dan sesudah intervensi.

Konsumsi lemak responden sebelum intervensi 77,1 $\pm 19,2$ dan sesudah intervensi $73,7 \pm 18,8$ serta hasil analisis diperoleh nilai $p$ value 0,048 . Hasil tersebut menunjukan bahwa ada perbedaan asupan konsumsi lemak sebelum dan sesudah intervensi.

Konsumsi karbohidrat sebelum intervensi $271,6 \pm 66,9$ dan $269,7 \pm 49,9$ sesudah intervensi, hasil analisis di dapat nilai $p$-value 0,779 . Hasil tersebut menunjukkan tidak ada perbedaan asupan KH sebelum da sesudah intervensi.

Pola makan merupakan salah satu faktor yang paling berperan dengan tingkat kejadian obesitas. Pola makan dipengaruhi oleh asupan energi, frekuensi makan, konsumsi fast food, konsumsi snack, serta tren makanan yang berkembang dikalangan remaja. Asupan energi sangat dibutuhkan untuk menghasilkan tenaga dalam tubuh. Berdasarkan hasil penelitian diperoleh prevalensi asupan energi remaja yang melebihi nilai dari kebutuhan rata-rata mencapai $120 \%$. Hal ini sangat dipengaruhi oleh tingkat pola konsumsi remaja dengan berbagai pertimbangan dalam pemilihan makanan seperti lebih memilih makanan siap saji dan makanan dan minuman manis.

\section{Konsumsi Buah dan Sayur}

Hasil penelitian diperoleh bahwa responden yang mengkonsumsi buah 46,96\%, banyak konsumsi buah responden masih jauh dibawah anjuran (150gr), hanya memenuhi $33,59 \%$ atau hanya $50,4 \pm 61,5 \mathrm{gr}$ pada pengukuran pertama dan $34,2 \%$ atau $51,3 \pm 67,1$ dari anjuran per hari 150gr. Begitu juga dengan konsumsi sayuran hanya $42,4 \%$ responden yang mengkonsumsi sayur, dimana konsumsinya juga masih sangat rendah dari jumlah yang dianjurkan (250gr), hanya $7,3 \%$ pada pengukuran pertama dengan $18,3 \pm 25,3$ dan $11,8 \%$ atau $29,5 \pm 31,4$ pada pengukuran kedua.

Anjuran konsumsi sayuran lebih banyak daripada buah karena buah juga mengandung gula, dimana kandungannya ada yang sangat 
tinggi sehingga rasa buah sangat manis dan juga ada yang jumlahnya cukup. Konsumsi buah yang sangat manis dan rendah serat agar dibatasi. Hal ini karena buah yang sangat manis mengandung fruktosa dan glukosa yang tinggi. Asupan fruktosa dan glukosa yang sangat tinggi berisiko meningkatkan kadar gula darah. Beberapa penelitian membuktikan bahwa konsumsi vitamin $\mathrm{C}$ dan vitamin $\mathrm{E}$ yang banyak terdapat dalam sayuran dan buah-buahan sangat bagus untuk melindungi jantung agar terhindar dari penyakit jantung koroner. Banyak keuntungan apabila konsumsi sayuran dan buah-buahan bagi kesehatan tubuh. Mengkonsumsi sayuran dan buah-buahan sebaiknya bervariasi sehingga 2 diperoleh beragam sumber vitamin ataupun mineral serta serat. Kalau ingin hidup lebih sehat lipat gandakan konsumsi sayur dan buah. Konsumsi sayur dan buah bisa dalam bentuk segar ataupun yang sudah diolah. Konsumsi sayuran hijau tidak hanya direbus ataupun dimasak tetapi bisa juga dalam bentuk lalapan (mentah) dan dalam bentuk minuman yaitu dengan ekstraksi sayuran dan ditambah dengan air tanpa gula dan tanpa garam. Khlorofil atau zat hijau daun yang terekstrak merupakan sumber antioksidan yang cukup bagus. Sayuran berwarna seperti bayam merah, kobis ungu, terong ungu, wortel, tomat juga merupakan sumber antioksidan yang sangat potensial dalam melawan oksidasi yang menurunkan kondisi tubuh (Kemenkes RI, 2014).

Hasil recall 24 jam responden diperoleh konsumsi buah terlihat ada perbedaan sebelum $50,4 \pm 7,6$ dan sesudah $51,3 \pm 67,1$ intervensi, namun hasil statistik menunjukkan tidak ada perbedaan yang bermakna dengan $p$-value 0,93 .

Begitu juga dengan konsumsi sayur terlihat ada perbedaan yang sebelum $18,3 \pm 25,2$ dan sesudah 29,5 $\pm 31,4$ intervensi. Hasil uji statistik menunjukkan ada perbedaan dengan $p$ value 0,022 .

Masyarakat Indonesia masih sangat kekurangan mengonsumsi sayuran dan buahbuahan, 63,3\% anak >10 tahun tidak mengonsumsi sayuran dan $62,1 \%$ tidak mengonsumsi buah-buahan. Padahal sayuran di Indonesia banyak sekali macam dan jumlahnya. Sayuran hijau maupun berwarna selain sebagai sumber vitamin, mineral juga sebagai sumber serat dan senyawa bioaktif yang tergolong sebagai antioksidan. Buah selain sebagai sumber vitamin, mineral, serat juga antioksidan terutama buah yang berwarna hitam, ungu, merah

Berbagai kajian menunjukkan bahwa konsumsi sayuran dan buah-buahan yang cukup turut berperan dalam menjaga kenormalan tekanan darah, kadar gula dan kolesterol darah. mengendalikan tekanan darah. Konsumsi sayur dan buah yang cukup juga menurunkan risiko sulit buang air besar (BAB/sembelit) dan kegemukan. Hal ini menunjukkan bahwa konsumsi sayuran dan buah-buahan yang cukup turut berperan dalam pencegahan penyakit tidak menular kronik. Konsumsi sayuran dan buahbuahan yang cukup merupakan salah satu indikator sederhana gizi seimbang (Kemenkes RI, 2014).

\section{Konsumsi Gula Garam dan Minyak}

Konsumsi gula, garam dan minyak yang dikonsumsi responden terlihat hanya konsumsi gula yang konsumsinya melebihi dari konsumsi yang dianjurkan, sementara konsumsi garam dan minyak masih dibawah konsumsi yang dianjurkan. Gula adalah karbohidrat sederhana merupakan sumber energi, ini mungkin juga yang menyebabkan konsumsi energi berlebih karena tingginya konsumsi gula dari yang dianjurkan.

Hasil penelitian terlihat bahwa ada perbedaan antara konsumsi gula sebelum $50,4 \pm 10,3$ dan sesudah $55,1 \pm 10,7$ intervensi, dengan hasil uji statistik diperoleh nilai $p$-value 0,001 . Angka konsumsi gula sudah sangat tinggi dari hasil analisi konsumsi gula pada SKMI 2014, dimana rata-rata konsumsi gula $25,1 \pm 23,2 \mathrm{gr}$ (Atmarita, dkk., 2017).

Gula yang dikonsumsi melampaui kebutuhan akan berdampak pada peningkatan berat badan, bahkan jika dilakukan dalam jangka waktu lama secara langsung akan meningkatkan kadar gula darah dan berdampak pada terjadinya diabetes tipe-2, bahkan secara tidak langsung berkontribusi pada penyakit seperti osteoporosis, penyakit jantung dan kanker.

Gula yang dikenal masyarakat tidak hanya terdapat pada gula tebu,gula aren dan gula jagung yang dikonsumsi dari makanan dan minuman Perlu diingat bahwa kandungan gula terdapat juga dalam makanan lain yang mengandung karbohidrat sederhana (tepung, roti, kecap). buah manis, jus, minuman bersoda dan sebagainya.

Begitu juga dengan konsumsi garam dimana hasil menunjukkan ada perbedaan antara konsumsi garam dengan sebelum $3,1 \pm 0,7$ dan sesudah intervensi $3,3 \pm 0,7$ hasil uji statistik di dapat nilai $p$-value 0,008 . Hasil ini berbeda dengan hasil analisis SKMI tahun 2014, dimana konsumsi garam mencapai $6,76 \pm 6$ pada usia 5-12 tahun dan 7,1 $\pm 6,7$ pada usia 13-18 tahun (Atmarita, dkk., 2017). 
Rasa asin yang berasal dari makanan adalah karena kandungan garam $(\mathrm{NaCl})$ yang ada dalam makanan tersebut. Konsumsi natrium yang berlebihan akan mempengaruhi kesehatan terutama meningkatkan tekanan darah. Karena itu dianjurkan mengonsumsi garam sekedarnya dengan cara menyajikan makanan rendah natrium: 1) Gunakan garam beriodium untuk konsumsi; 2) Jika membeli pangan kemasan dalam kaleng, seperti sayuran, kacang-kacangan atau ikan, baca label informasi nilai gizi dan pilih yang rendah natrium; 3) Jika tidak tersedia pangan kemasan dalam kaleng yang rendah natrium, pangan dalam kemasan tersebut perlu dicuci terlebih dahulu agar sebagian garam dapat terbuang; 4) Gunakan mentega atau margarine tanpa garam (unsalted); 5) Jika mengonsumsi mi instan, gunakan sebagian saja bumbu dalam sachet bumbu yang tersedia dalam kemasan mi instan; 6) Coba bumbu yang berbeda untuk meningkatkan rasa makanan, sepert jahe atau bawang putih. Sedangkan konsumsi lemak menunjukkan ada perbedaan yang berarti sebelum dan sesudah intervensi dengan nilai $p$ value 0,048 .

Lemak yang terdapat didalam makanan, berguna untuk meningkatkan jumlah energi, membantu penyerapan vitamin $\mathrm{A}, \mathrm{D}, \mathrm{E}$ dan $\mathrm{K}$ serta menambah lezatnya hidangan. Konsumsi lemak dan minyak dalam hidangan sehari-hari dianjurkan tidak lebih dari $25 \%$ kebutuhan energi, jika mengonsumsi lemak secara berlebihan akan mengakibatkan berkurangnya konsumsi makanan lain. Hal ini disebabkan karena lemak berada didalam sistem pencernaan relatif lebih lama dibandingkan dengan protein dan karbohidrat, sehingga lemak menimbulkan rasa kenyang yang lebih lama. Secara nasional, rata-rata konsumsi lemak di Indonesia telah sesuai dengan yang dianjurkan yaitu $67 \mathrm{gr} / \mathrm{kapita} / \mathrm{hari}$ atau $25 \%$ dari total konsumsi energi. Karakteristiknya adalah lebih besar pada kelompok penduduk usia 2-18 tahun, tinggal di perkotaan dan pada kelompok perempuan (Riskesdas, 2010). Hasil analisis Survei Konsumsi Makanan Individu (SKMI) tahun 2014, diperoleh konsumsi lemak usia 5-12 tahun $57,2 \pm 34,6$ gr dan usia 13-18 tahun 57,2 $\pm 39,5 \mathrm{gr}$. (Atmarita, dkk., 2017).

\section{Konsumsi Makanan dan Minuman Manis}

Frekuensi konsumsi minuman manis perhari mencapai $3,8 \pm 0,8$ pada pengukuran pertama dan $3,1 \pm 0,8$ pada pengukuran kedua. Sementara frekuensi konsumsi makanan manispun tidak jauh berbeda yaitu $3,7 \pm 0,8$ pada pengukuran pertama dan $3,4 \pm 1,0$ pada pengukuran kedua. Konsumsi makanan manis cukup tinggi dimana konsumsi makanan manis rata-rata hampir 4 porsi per hari begitu juga dengan minuman manis. Konsumsi makanan dan minuman manis mencapai 7 kali sehari.

Hasil penelitian menunjukkan konsumsi makanan dan minuman manis cukup tinggi/harinya, konsumsi minuman manis sebelum $3,8 \pm 0,8$ dan sesudah $3,1 \pm 0,8$ intervensi dengan nilai $p$-value 0,363 . Sedangkan untuk makanan manis menunjukkan ada perbedaan sebelum $3,8 \pm 0,8$ dan sesudah intervensi $3,7 \pm 0,7$ dengan nilai $p$-value 0,025 .

Frekuensi konsumsi makanan dan minuman manis responden cukup tinggi rata-rata mencapai 4 kali, jika ditambahkan keduanya ratarata mencapai 8 kali, pengukuran setelah intervensi terlihat ada perbedaan yaitu terjadi penurunan, namun secara statistik untuk minuman manis perbedaannya tidak signifikan berbeda dengan frekuensi makanan manis terlihat ada perbedaan yg signifikan

\section{Aktivitas Fisik}

Aktivitas fisik responden juga sangat rendah yaitu rata-rata hanya 1,97 pada pengukuran pertama dan 2,2 pada pengukuran kedua. Aktivitas fisik yang meliputi segala macam kegiatan tubuh termasuk olahraga merupakan salah satu upaya untuk menyeimbangkan antara pengeluaran dan pemasukan zat gizi utamanya sumber energi dalam tubuh. Aktivitas fisik memerlukan energi.Selain itu, aktivitas fisik juga memperlancar sistem metabolisme di dalam tubuh termasuk metabolisme zat gizi. Oleh karenanya, aktivitas fisik berperan dalam menyeimbangkan zat gizi yang keluar dari dan yang masuk ke dalam tubuh.

Menurun dan rendahnya aktivitas fisik dipercaya sebagai salah satu hal yang menyebabkan obesitas. Tren kesehatan terkini juga menunjukkan prevalensi obesitas meningkat bersamaan dengan meningkatnya perilaku secondary dan berkurangnya aktivitas fisik. Perilaku sedentari adalah perilaku duduk atau berbaring dalam sehari-hari baik di tempat kerja (kerja di depan komputer, membaca, dll), di rumah (nonton TV, main game, dll).

Meenu, S \& Madhu, S, (2005) menyatakan bahwa kehilangan aktivitas fisik, akibat menonton televisi atau bermain video game lebih dari 1 (satu) jam setiap hari memiliki kontribusi yang signifikan terhadap obesitas pada anak dan remaja. Pendapat ini diperkuat dengan 
ditemukannya data aktivitas fisik pada penelitian dimana remaja lebih banyak menghabiskan waktu dengan melakukan aktivitas pada posisi duduk dan berbaring seperti menonton televisi, mengerjakan tugas, bermain game atau hanya sekedar menghabiskan waktu dengan bersantai, bahkan pada hari libur remaja bisa menghabiskan 10-12 jam dengan melakukan berbagai aktivitas pada posisi duduk dan berbaring dalam sehari.

\section{Peran Orang Tua sebagai Role Model}

Orang tua sangat berperan terhadap konsumsi makanan anak, hasil penelitian menunjukkan bahwa $100 \%$ ibu menyediakan sayur dalam makanan sehari-hari, namun hanya $42,4 \%$ responden yang mengkonsumsi sayur. Sementara untu persediaan buah-buahan hanya $19,7 \%$ orang tua menyiapkan buah-buhan dalam makanan sehari-hari, namun konsumsi buah anak mencapai $49,9 \%$ hal ini dlkarenakan anak membeli buah potong yang dijual oleh pedagang keliling da nada juga yang diberi oleh tetangga. Sedangkan ibu yang melakukan aktifitas fisik hanya $10,6 \%$. Terlihat peran orang tua khususnya ibu dalam menyiapkan konsumsi buah dan aktifitas fisik masih sangat rendah.

Hasil penelitian menunjukkan bahwa aktifitas fisik siswa sebelum intervensi dengan nilai mean (min-max) sebesar 2,2 (1-3,8) dan rata-rata 2,2 $\pm 0,5$ Aktifitas fisik sesudah intervensi diperoleh nilai mean 2,4 (1,3-4,5) dan rata-rata $2,4 \pm 0,5$. Hasil analisis diperoleh nilai $p$ value 0,008 yang menunjukkan ada perbedaan sebelum dan sesudah intervensi.

Meski aktivitas fisik hanya mempengaruhi satu pertiga pengeluaran energi seseorang dengan berat normal, tapi bagi orang yang memiliki kelebihan berat badan aktivitas fisik memiliki peran yang sangat penting. Pada saat berolahraga kalori terbakar, makin banyak berolahraga maka semakin banyak kalori yang hilang. Kalori secara tidak langsung mempengaruhi sistem metabolisme basal. Orang yang duduk bekerja seharian akan mengalami penurunn metabolisme basal tubuhnya. Kekurangan aktifitas gerak akan menyebabkan suatu siklus yang hebat, obesitas membuat kegiatan olah raga menjadi sangat sulit dan kurang dapat dinikmati dan kurangnya olah raga secara tidak langsung akan mempengaruhi turunnya metabolisme basal tubuh orang tersebut. Jadi olahraga sangat penting dalam penurunan berat badan tidak saja karena dapat membakar kalori, melainkan juga karena dapat membantu mengatur berfungsinya metabolis normal (Vizcaíno, et al., 2008).

Aktivitas fisik adalah hal yang dianjurkan terhadap setiap orang untuk mempertahankan dan meningkatkan kesegaran tubuh. Aktivitas fisik berguna untuk melancarkan peredaran darah dan membakar kalori. Menurun dan rendahnya aktivitas fisik dipercaya sebagai salah sa tu hal yang menyebabkan obesitas. Tren kesehatan terkini juga menunjukkan prevalensi obesitas meningkat bersamaan dengan meningkatnya perilaku sedentari dan berkurangnya aktivitas fisik. Perilaku sedentari adalah perilaku duduk atau berbaring dalam sehari-hari baik di tempat kerja (kerja di depan komputer, membaca, dll), di rumah (nonton TV, main game, dll), di perjalanan/transportasi (bis, kereta, motor), tetapi tidak termasuk waktu tidur. Perilaku sedentari merupakan perilaku berisiko terhadap salah satu terjadinya penyakit penyumbatan pembuluh darah, penyakit jantung dan bahkan mempengaruhi umur harapan hidup. Penelitian tentang analisis aktivitas ringan sebagai faktor risiko terjadinya obesitas pada remaja di Sekolah Menengah Pertama Negeri 1 Manado menunjukkan hasil siswa yang obes memiliki aktivitas fisik ringan dengan rata-rata total MET 577,56 MET/minggu dan siswa tidak obes sebagian besar memiliki aktivitas fisik sedang dengan rata-rata total MET 785,62 MET/minggu (Sawello, 2012). Hal ini juga menunjukkan bahwa aktivitas fisik merupakan faktor risiko terhadap kejadian obesitas dimana remaja dengan aktivitas fisik ringan 6,591 kali lebih berisiko menjadi obes, dibandingkan dengan remaja dengan aktivitas fisik sedang.

\section{SIMPULAN}

Ada perbedaan asupan lemak, konsumsi gula, garam dan lemak, konsumsi sayur, aktivitas fisik, dan konsumsi makanan manis sebelum dan sesudah intervensi. Peran ibu sebagai role model diketahui keseluruhan ibu menyediakan sayur, hanya $19,7 \%$ menyiapkan buah setiap harinya dan hanya $10,6 \%$ ibu melakukan aktifitas fisik.

Berdasarkan simpulan di atas, maka diharapkan Puskesmas dapat bekerja sama dengan pihak sekolah dan keluarga melalui Posbindu dalam penanggulangan program obesitas dengan melakukan penyuluhan di sekolah dan melakukan penilaian status gizi. 


\section{DAFTAR PUSTAKA}

Atmarita, A., Jahari, A. B., Sudikno, S., \& Soekatri, M. (2017). Asupan Gula, Garam, dan Lemak di Indonesia: Analisis Survei Konsumsi Makanan Individu (SKMI) 2014. Gizi Indonesia, 39(1), 1-14.

Depkes RI. (2008). RISKESDAS 2007. Jakarta: Badan Penelitian dan Pengembangan Kesehatan.

Depkes RI. (2010). RISKESDAS 2010. Jakarta: Badan Penelitian dan Pengembangan Kesehatan.

GBD 2015 Obesity Collaborators. (2017). Health effects of overweight and obesity in 195 countries over 25 years. New England Journal of Medicine, 377(1), 13-27

Kemenkes RI. (2013). RISKESDAS 2013. Jakarta: Badan Penelitian dan Pengembangan Kesehatan.

Kemenkes RI. (2018). Buku Saku Pemantauan Status Gizi Tahun 2018. Direktorat Gizi Masyarakat Dirjen Binkesmas.

Kemenkes RI. (2018). RISKESDAS 2018. Badan Penelitian dan Pengembangan Kesehatan.

Kemenkes RI. (2014). Waspadai Bahaya Obesitas, Cara Sehat Menurunkan Berat Badan. Direktorat Jenderal Pengendalian Penyakit dan Penyehatan Lingkungan, Direktorat Pengendalian Penyakit Tidak Menular.

Meenu, S. \& Madhu, S. (2005). Risk Factors for Obesity in Children, Department of
Pediatrics,Advanced Pediatric Center, Postgraduate Institute of Medical Education and Research, Chandigarh, India. Indian pediatrics 42(2): 183-5 March 2005.

Sartika, R. A. D. (2011). Faktor risiko obesitas pada anak 5-15 tahun di Indonesia. Makara kesehatan, 15(1), 37-43

Sawello, M. A., \& Malonda, N. S. (2012). Analisis Aktivitas Ringan Sebagai Faktor Risiko Terjadinya Obesitas Pada Remaja Di Sekolah Menengah Pertama Negeri 1 Manado. Jurnal Kesehatan Masyarakat Universitas Sam Ratulangi Manado. http://jkesmasfkm.unsrat.ac.id/wpcontent/uploads/2013/02/71.pdf

Vizcaíno, V. M., Aguilar, F. S., Gutiérrez, R. F., Martínez, M. S., López, M. S., Martínez, S. S., ... \& Artalejo, F. R. (2008). Assessment of an after-school physical activity program to prevent obesity among 9-to 10-year-old children: a cluster randomized trial. International journal of obesity, 32(1), 12-22.

Wulandari, S., Lestari, H., \& Fachlevy, A. F. (2017). Faktor yang Berhubungan dengan Kejadian Obesitas pada Remaja di SMA Negeri 4 Kendari Tahun 2016. Jurnal Ilmiah Mahasiswa Kesehatan Masyarakat, 1(3). 